\section{FLOODS OF SEPTEMBER 1938 IN NEW ENGLAND}

$\mathrm{T}$ $\mathrm{HE}$ hurricane which visited New England in September 1938 is rather artlessly described in a massive volume of 562 pp. as "the greatest catastrophe since settlement by the white man"*. The loss of life was very heavy and the material damage by flood, wind and wave exceeded three hundred million dollars. The greater part of the damage was caused by flooding of the rivers resulting from heavy rain, and coming so soon after the great floods of March 1936 it caused much alarm. The U.S. Geological Survey has accordingly collected all the available information about rainfall and river-levels as a basis for the design of protective measures for the future.

The antecedent conditions were unfavourable but not in themselves dangerous. In the preceding months rainfall had been above normal, and by September 11 there was an accumulated surplus of moisture in the ground. Heavy rain during September 12-16 added to this, but though the rivers ran bank high there was no flooding. On September 16 there was even some improvement, but from September 17 onwards the weather was consistently unfavourable. On September 19 a trough of low pressure lay over New England in which moist tropical air moved northwards, giving falls exceeding 5 in. in twenty-four hours. Meanwhile a tropical hurricane was moving rapidly northwards near the coast. As a rule these hurricanes keep well to the east, but this one was diverted into the open trough of low pressure, and on September 21 moved rapidly inland towards the Canadian border. On the eastern side of the centre the winds reached hurricane force, doing widespread damage, and the rainfall was torrential, but with the passage of the centre the rain ceased abruptly. In the twenty-four hours ending at 6 p.m. on September 21,6 in. or more fell over 1,020 square miles, and floods which, though severe, might have been manageable, burst all bounds.

Rainfall charts are given day by day and again for every twelve hours, but since the effect of flood rains is largely cumulative, greatest interest centres in the map for the whole period September 17-21. The distribution is remarkable, for while there was a rainfall of $6-10$ in. in these five days over a very wide area, the greatest amounts of $10 \mathrm{in}$. to more than 17 in. were confined to a comparatively narrow belt along the hurricane track northwards from Long Island, comprised mainly within the basins of the Connecticut, Merrimack and Thames Rivers. Over an area of 100 square miles in Connecticut and central Massachusetts the rainfall exceeded 16 in., equivalent to the total average rainfall in London from January to September inclusive. On the eastern side of this belt the rainfall diminished almost abruptly, so that the coast of Massachusetts received only a few inches, but on the western side the decrease was more gradual and flooding extended for some distance with decreasing severity. In many places on the smaller streams in the central belt the crest of the flood reached levels several feet higher than any previously recorded. The tables of flood height and discharge which make up a great part of the book show instances of discharges which were only a few

* Hurricane Floods of September 1938. U.S. Geological Survey Water-Supply Paper 867, 1940. cubic feet per second per square mile of drainage area on September 18 and $100 \mathrm{cub}$. ft. on the morning of September 21, but had risen to 400 or $500 \mathrm{cub}$. ft. a few hours later. On the larger rivers the rise was naturally slower as various tributaries came in at different stages, but the. cumulative effect was as great. Under the pressure of the water, dams and bridges gave way and the rivers spread over their flood plains, destroying roads, railways and houses; the damage is vividly shown by a fine series of photographs.

The coasts naturally did not suffer from river flooding, but they were swept by a great storm wave, which in the eastern areas coincided with the normal time of high tide and rose to heights of $10 \mathrm{ft}$. and, where the waters were heaped up in narrow channels, more than $17 \mathrm{ft}$. above the average level of high water; New York's holiday coast was devastated, scores of houses being completely demolished.

The flood problem of rivers in populous country is one of great complexity. To enable the waters to flow away freely and naturally, the flood plain should be kept unobstructed, but the life of the towns and villages depends on the river, and encroachments are hard to avoid, while it is to these low-lying settlements that the danger is greatest. Reservoirs, whether constructed specially for the purpose of controlling flood water or for other purposes, play a useful part in minimizing the rise, but if the river sweeps away the obstructing barrier and empties the reservoir, the sudden influx of stored water may add to the catastrophe; in fact, many of the curves of flood height show a double crest due to this cause. The volume of flood water depends on the absorption of the ground as well as on the rainfall; the great flood of March 1936 was magnified by the melting of the snow and by the imperviousness of the ground, which threw practically the whole of the rain-water into the rivers ; by contrast in September 1938 the ground, in spite of its previous soaking, managed to absorb a good deal of the earlier rainfall, though it could not cope with the torrential downpour of the last day.

Hurricanes have visited New England before, and will doubtless do so again, but this detailed record compiled by the U.S. Geological Survey will at least provide American engineers with the data for plans to minimize, though they are unlikely to be able entirely to avert, the effects of future visitations.

C. E. P. Brooks.

\section{BIOGEOGRAPHIC DIVISION OF THE INDO-AUSTRALIAN ARCHIPELAGO}

$\mathrm{O}^{\mathrm{N}}$ April 16 and 30 a discussion was held by the Linnean Society under the chairmanship of the president, Dr. E. S. Russell, on "the biogeographic division of the Indo-Australian Archipelago, with criticism of the Wallace and Weber lines and of any other dividing lines, and with an attempt to obtain uniformity in the names used for the divisions". The following papers were contributed: $\mathrm{Mr}$. J. B. Scrivenor, "Geological and climatic factors affecting the distribution of life in the Indo-Australian Archipelago"; Mr. I. H. Burkill, "A historic account of the divisions which have been proposed"; Dr. 